\title{
Pengaruh Perendaman Daging Sapi dalam Larutan Rimpang Kunyit (Curcuma domestica val.) dengan Kombinasi Konsentrasi dan Lama Waktu Penyimpanan Terhadap Total Jumlah Bakteri
}

\author{
(EFFECT OF SOLUTION Curcuma domestica Val. ON BEEF MEAT WITH \\ CONCENTRATION COMBINATION AND STORAGE TIME ON TOTAL AMOUNT OF \\ BACTERIA)
}

\author{
Tri Lestari ${ }^{1 *}$, Boedi Setiawan², Ratih Novita Praja ${ }^{3}$, Ratna Damayanti ${ }^{4}$, Ragil Angga \\ Prastiya $^{5}$, Prima Ayu Wibawati ${ }^{6}$ \\ ${ }^{1}$ Bachelor of Veterinary Medicine, \\ ${ }^{2}$ Department of Veterinary Clinic and Animal Hospital, \\ ${ }^{3}$ Department of Veterinary Microbiology, \\ ${ }^{4}$ Department of Basic Veterinary Science, \\ ${ }^{5}$ Department of Veterinary Reproduction, \\ ${ }^{6}$ Department of Veterinary Public Health, \\ Faculty of Veterinary Medicine, Universitas Airlangga, \\ UNAIR C-Campus Mulyorejo, Surabaya, Jawa Timur, Indonesia, 60115 \\ Telp. (031)5993016, Fax. (031)5993015 \\ *Corresponding author: tri.lestari-2014@fkhunair.ac.id
}

\begin{abstract}
Abstrak
Tujuan penelitian ini adalah untuk mengetahui pengaruh antibakteri dari larutan rimpang kunyit (Curcuma domestica Val.) terhadap total jumlah bakteri pada sapi dengan kombinasi antara konsentrasi dan lama penyimpanan. Sampel daging sapi dibagi menjadi 60 buah dan masing-masing sampel adalah 25 gram. Metode penelitian adalah rancangan acak lengkap dengan menggunakan 4 konsentrasi larutan rimpang kunyit 0 gr 100 ml-1, 20 gr 100 ml-1, 40 gr 100 ml-1, 60 gr 100 ml-1 dan disimpan dalam waktu berdurasi 0 jam, 3 jam, 6 jam. Data yang diperoleh dianalisis oleh menggunakan Anava. Hasil penelitian ini menunjukkan perbedaan yang signifikan $(\mathrm{p}<0,05)$ antara kontrol dan perlakuan pada total jumlah koloni bakteri. Berdasarkan hasil dapat disimpulkan bahwa larutan rimpang kunyit berpengaruh pada penurunan jumlah koloni bakteri.
\end{abstract}

Kata kunci: Curcuma domestica val, antibakteri, total plate count, daging, lama penyimpanan

Abstract

The aim of this research was to know the antibacterial effect of turmeric rhizome solution (Curcuma domestica Val.) to total number of bacteria in beef with combination between concentration and length of storage time. The beef samples were divided into 60 pieces and each sample was 25 grams. The research method used completely randomized design (CRD) by four consentrations of turmeric rhizhome solution $0 \mathrm{gr}$ $100 \mathrm{ml}-1,20 \mathrm{gr} 100 \mathrm{ml}-1,40 \mathrm{gr} 100 \mathrm{ml}-1,60 \mathrm{gr} 100 \mathrm{ml}-1$ and were storaged in a normal room temperature with the duration time 0 hours, 3 hours, 6 hours respectively. The obtained data were analyzed by Analysis of Variance (ANAVA) and continued by Duncan multiple test. The result of this research showed significanly different $(p<0,05)$ between the contol and the best consentrations $(20 \mathrm{gr} 100 \mathrm{ml}-1$ and $40 \mathrm{gr} 100 \mathrm{ml}-1)$ in the storage time 3 hours in the total of number bacterial colonies. Based on those result, it could be concluded that turmeric rhizome solution affected in decreasing the number of bacterial colonies.

Key words: Curcuma domestica val, antibacterial, beef, total plate count, storage time

\section{PENDAHULUAN}

Daging berperan cukup besar dalam konteks ketahanan pangan nasional karena merupakan salah satu komoditas dengan kandungan gizi yang cukup lengkap (Usmiati, 2010). Nilai gizi yang tinggi menyebabkan Produk hasil ternak juga mempunyai resiko tinggi terhadap kontaminasi bakteri, sehingga diperlukan adanya penanganan yang baik untuk 
memperpanjang masa simpan daging (Rahayu, 2006). Mukartini et al., (1995) menambahkan bahwa Kontaminasi mikroba pada daging sapi dapat berasal dari peternakan dan rumah potong hewan yang tidak higienis, begitu juga sumber air dan lingkungan tempat diolahnya daging tersebut sebelum sampai kepada konsumen.

Menurut Harsojo dkk., (2005), daging segar yang tidak langsung diolah akan cepat mengalami pembusukan karena adanya aktivitas bakteri. Jaringan hewan sehat umumnya bebas dari bakteri pada saat dipotong, tetapi ketika diperiksa daging segar pada tingkat penjual retail selalu ditemukan berbagai jenis dan jumlah mikroorganisme (Jay et al., 2005). Purwani dkk (2008), berhasil mengisolasi beberapa bakteri yang terdapat pada daging sapi segar yaitu Acinobacter calcoaciticus, Escherichia Coli, Salmonella, Pseudomonas aeruginosa, Bacillus alvei, Bacillus cerevus dan Staphylococcus sp.

Hasil penelitian menunjukkan bahwa rempah-rempah dan bumbu asli indonesia ternyata banyak mengandung senyawa antimikroba salah satunya adalah kunyit yang berpotensi untuk dijadikan sebagai pengawet alami. Senyawa bioaktif yang berperan sebagai antimikrobia adalah minyak atsiri, kurkumin, desmetoksikumin dan bidestometoksikumin (Rahardjo, 2004). Respon daya hambat pertumbuhan mikroba yang dihasilkan dipengaruhi oleh kandungan senyawa aktif yang terdapat dalam kunyit seperti minyak atsiri, alkaloid, flavonoid, tanin, kurkuminoid dan terpenoid (Rukmana, 2004). Senyawa fenol seperti kurkumin mampu berinteraksi dengan dinding sel bakteri, selanjutnya terabsorbsi dan penetrasi kedalam sel bakteri, sehingga menyebabkan denaturasi protein yang akan melisiskan membran sel bakteri (Tarwiyah, 2001).

Tujuan penelitian untuk mengetahui pengaruh perendaman larutan rimpang kunyit (Curcuma domestica Val.) terhadap penurunan total jumlah bakteri pada daging sapi dengan kombinasi konsentrasi dan lama waktu penyimpanan.

\section{METODE PENELITIAN}

Penelitian ini dilakukan di Laboratorium Mikrobiologi Prodi Kedokteran Hewan PSDKU Universitas Airlangga Banyuwangi. Sampel penelitian yang digunakan adalah daging sapi segar 1500 gr dibagi menjadi 60 bagian untuk 5 kali ulangan dan setiap sampel memiliki berat 25 gr yang diambil di pasar tradisional Banyuwangi. Rimpang kunyit dengan konsentrasi 0 gr per 100 $\mathrm{ml}, 20$ gr per $100 \mathrm{ml}, 40$ gr per $100 \mathrm{ml}$, dan $60 \mathrm{gr}$ per $100 \mathrm{ml}$ aquadest steril, dengan lama waktu penyimpanan 0 jam, 3 jam, dan 6 jam.

Bahan yang digunakan dalam penelitian ini antara lain rimpang kunyit, daging sapi segar 1500 gr (60 sampel/25 gr), aquadest steril, spiritus, nutrient agar (NA), Buffer Pepton Water (BPW $1 \%$ ), dan kertas $\mathrm{pH}$.

Alat yang digunakan dalam penelitian adalah timbangan, labu Erlenmeyer $500 \mathrm{ml}$, pipet volume, Cawan Petri Disk, bunsen, tabung reaksi dan inkubator.

Alat untuk membuat larutan perendaman kunyit adalah parutan kelapa, timbangan digital, saringan, mangkuk bening, dan pengaduk.

Pembuatan larutan rimpang kunyit dengan konsentrasi 20 gr per $100 \mathrm{ml}, 40$ gr per $100 \mathrm{ml}$, 60 gr per $100 \mathrm{ml}$ yaitu rimpang kunyit dipilih yang muda dan besar serta berbau harum, kemudian dicuci dan dibersihkan, untuk konsentrasi 20 gr per $100 \mathrm{ml}$ rimpang kunyit kemudian diparut, ditimbang seberat 20 gr setelah itu ditambahkan $100 \mathrm{ml}$ aquadest steril, kemudian di diamkan selama 15 menit untuk mendapatkan saripatinya, disaring dan dletakan di gelas kaca yang berisi daging, direndam selama 30 menit dan ditutup alumunium foil (Suryawati dkk., 2011).

Pemeriksaan total jumlah bakteri dengan menggunkan meode Total Plate Count (TPC) yaitu dagng sapi dipotong dengan berat $25 \mathrm{gr}$, dan dipindahkan kedalam tabung erlenmayer steril. Sebanyak $25 \mathrm{gr}$ daging sapi kemudian diencerkan dengan $225 \mathrm{ml}$ BPW 1\% kocok baikbaik sehingga diperoleh larutan pengenceran 101 kemudian di homogenkan. Sebanyak $0,1 \mathrm{ml}$ larutan pengenceran 10-1 yang sudah dihomogenkan, dimasukan kedalam tabung reaksi yang berisi $9,9 \mathrm{ml}$ larutan BPW $1 \%$ 
dikocok sampai homogen sehingga diperoleh larutan pengenceran 10-3. Sebanyak 1 ml larutan pengenceran 10-3 yang sudah dihomogenkan, dimasukan kedalam tabung reaksi yang berisi 9 $\mathrm{ml}$ larutan BPW 1\% dikocok sampai homogen sehingga diperoleh larutan pengenceran 10-4. Sebanyak $1 \mathrm{ml}$ larutan pengenceran 10-4 yang sudah dihomogenkan, dimasukan kedalam tabung reaksi yang berisi $9 \mathrm{ml}$ larutan BPW 1\% dikocok sampai homogen sehingga diperoleh larutan pengenceran 10-5 . Masing-masing pengenceran diambil $1 \mathrm{ml}$, kemudian dituang kedalam cawan petri steril yang sudah diberi tanda nomor sampel. Nutrient agar cair dituangkan ke dalam masing-masing cawan petri yang terisi sampel, kemudian digoyangkan pada bidang datar agar larutan tersebut tercampur rata, dibiarkan dingin. Kemudian dimasukan dalam inkubator dalam keadaan terbalik, diinkubasi selama 24 jam pada suhu $37^{\circ} \mathrm{C}$. Kemudian koloni yang tumbuh dalam cawan petri dihitung berdasarkan SPC (Standart Plate Count) (Prawesthirini dkk., 2016).

\section{HASIL DAN PEMBAHASAN}

Daging sapi yang telah direndam dengan larutan rimpang kunyit dengan perbedaan waktu penyimpanan kemudian di hitung total jumlah bakterinya.

Tabel 1 menunjukan rata-rata tertinggi jumlah bakteri daging sapi pada dosis 0 gr per $100 \mathrm{ml}$ dengan lama penyimpanan 6 jam yaitu $5,29 \pm 3,87$ Tingginya jumlah bakteri pada perlakuan 0 gr per $100 \mathrm{ml}$ disebabkan tidak adanya komponen antibakteri pada bahan pangan. Fardiaz (1992) menyatakan bahwa pertumbuhan koloni bakteri dipengaruhi oleh ada tidaknya komponen antibakteri pada bahan pangan.

Tabel 1. Rata-rata dan Standard Deviasi interaksi konsentrasi larutan rimpang kunyit dan lama penyimpanan terhadap jumlah koloni bakteri daging sapi

\begin{tabular}{ccccc}
\hline Lama & \multicolumn{4}{c}{ Konsentrasi } \\
\cline { 2 - 5 } Penyimpanan & $\begin{array}{c}\text { 0 gr per 100 ml } \\
\text { (P0) }\end{array}$ & $\begin{array}{c}\text { 20 gr per 100 ml } \\
\text { (P1) }\end{array}$ & $\begin{array}{c}\text { 40 gr per 100 ml } \\
\text { ( P2) }\end{array}$ & $\begin{array}{c}\text { 60 gr per 100 ml } \\
\text { (P3) }\end{array}$ \\
\hline 0 Jam (L1) & $4,93^{b c d} \pm 2,49$ & $4,59^{a b} \pm 2,63$ & $4,47^{a b} \pm 3,33$ & $4,73^{a b c} \pm 2,42$ \\
3 Jam (L2) & $4,95^{b c d} \pm 2,88$ & $4,29^{a} \pm 4,19$ & $4,39^{a} \pm 2,96$ & $4,62^{a b c} \pm 2,93$ \\
6 Jam (L3) & $5,29^{d} \pm 3,87$ & $4,64^{a b c} \pm 4,93$ & $4,68^{a b c} \pm 1,87$ & $5,10^{c d} \pm 4,54$ \\
\hline
\end{tabular}

Dosis terbaik yaitu pada konsentrasi 20 gr per $100 \mathrm{ml}$ dan 40 gr per $100 \mathrm{ml}$ dengan lama penyimpanan 3 jam yaitu 4,29 $\pm 4,19$ dan $4,39 \pm 2,96$. Penurunan total jumlah baketri pada daging sapi disebabkan kandungan zat yang ada pada rimpang kunyit yang bersifat sebagai antibakteri (Rahman, 2009). Zat-zat yang terkandung dalam kunyit antara lain adalah golongan terpenoid penyusun minyak atsiri dimana dapat merusak membran biologis sel atau asosiasi enzim sehingga pertumbuhan bakteri akan terhambat (Marwati, 1996).

Selain minyak atsiri, kurkumin juga merupakan senyawa yang terdapat pada kunyit yang bersifat sebagai antibakteri. Kurkumin dalam rimpang kunyit merupakan senyawa fenolik yang bersifat sebagai antimikroba adalah fenol, gingerol, zingerberen, halogen dan etiloksida (Pandiangan, 2008), sebagai senyawa fenolik mekanisme kerja kurkumin sebagai antibakteri mirip dengan persenyawaan fenol lainnya yaitu menghambat metabolisme bakteri dengan cara merusak membran sitoplasma dan mendenaturasi prtotein sel yang menyebabkan kebocoran nutrien dari sel sehingga sel bakteri mati atau terhambat pertumbuhannya (Azima, 2011).

Kerja senyawa antimikroba adalah merusak dinding sel. Kerusakan dinding sel akan menyebabkan gangguan permeabilitas sel sehingga menyebabkan berkurangnya kemampuan sel bakteri dalam menjaga keutuhan struktur sel (Mawaddah, 2008).

Pada dosisi 60 gr per $100 \mathrm{ml}$ belum dapat menurunkan total jumlah bakteri, karena jumlah 
total bakteri yang dihasilkan lebih tinggi dari dosis 20 gr per $100 \mathrm{ml}$ dan 40 gr per $100 \mathrm{ml}$ tetapi tidak melebihi total jumlah bakteri pada dosis 0 gr per $100 \mathrm{ml}$. Disimpulkan bahwa peningkatan konsentrasi dari antibakteri tidak selalu menyebabkan jumlah koloni bakteri yang berbeda atau semakin rendah. Menurut Maleki et al., (2008), konsentrasi yang terlalu pekat menyebabkan larutan tersebut sulit berdifusi secara maksimal kedalam medium. Konsentrasi yang lebih tingi dapat terjadi kejenuhan sehingga menyebabkan senyawa-senyawa aktif yang terkandung dalam larutan tersebut tidak terlarut dengan sempurna.

\section{KESIMPULAN}

Dapat disimpulkan bahwa terdapat penurunan total jumlah bakteri pada daging sapi dalam perendaman larutan rimpang kunyit (Curcuma domestica val.) dengan kombinasi konsentrasi dan lama waktu penyimpanan terhadap total jumlah bakteri.

\section{UCAPAN TERIMA KASIH}

Penulis mengucapkan terima kasih kepada staf laboratorium mikrobiologi prodi Kedokteran Hewan PSDKU Banyuwangi dan rekan mahasiswa yang telah membantu sehingga penelitian dapat berjalan dengan baik.

\section{DAFTAR PUSTAKA}

Azima. 2011. Efektivitas Kunyit Sebagai Bahan Pengawet Alami Terhadap Masa Simpan Nugget Jagung.

Fardiaz, S. 1992. Mikrobiologi Pengelolaan Pangan. Departemen Pendidikan dan Kebudayaan Direktorat Jendral Pendidikan Tinggi, Pusat Antar Universitas Pangan dan Gizi. Institut Pertanian Bogor. Bogor.

Harsojo, Andini, L. S., Trimey, R. S. 2005. "Dekontaminasi Bakteri Patogen pada Daging dan Jeroan Kambing dengan Iridiasi
Gamma” Seminar Nasional Teknologi Peternakan dan Veteriner.

Jay, J. M., Loessner, M. J., Golden, D.A. 2005. Modern Food Microbiology Seventh Edition. Springer Science and Bussiness Media Inc., USA.

Maleki, S., Seyyednejad, S. M., Damabi, M. N., Motamedi, H. 2008. Antibacterial activity of the fruits of Irianian Torilis leptophylla againts some clinical pathogens. Pak. J. Biol. Sci., 11(9), 1286-1289.

Marwati, T. 1996. Aktivitas Zat Anti Bakteri Pada Rimpang Kunyit.

Mukartini, S., Jehne, C., Shay, B., Harfer, C. M. L. 1995. Microbiological status of beef carcass meat in Indonesia. J. Food Safety, 15, 291-303.

Pandiangan, 2008. Kajian Aktivitas Antimikroba Ekstrak Kunyit (Curcuma domestica Val) Terhadap Bakteri Patogen.

Rahman, M. 2009. Aktivitas Anti Bakteri Senyawa Hasil Biotransformasi Kurkumin Oleh Mikrob Endofil Asal Kunyit.

Rahardjo, M., Rostiana, O. 2004. Standar prosedur Operasional Budidaya Kunyit dalam Standar Prosedur Operasional Jahe, Kencur, Kunyit dan Temulawak. Badan Litbang Pertanian. Balitro-Bogor. p46.

Rahayu, E. S. 2006. Amankan Produk Pangan Kita : Bebaskan dari Cemaran Berbahaya. Apresiasi peningkatan mutu hasil olahan pertanian. Yogyakarta : Dinas Pertanian Propinsi DIY dan Kelompok Pemerhati Keamanan Mikrobiologi Produk Pangan.

Rukmana, R. 2004, Temu-temuan Apotik Hidup di Pekarangan, Yogyakarta: Kanisius.

Suryawati, A., Meikawati, W., Astuti, R. 2011. Pengaruh Dosis dan Lama Perendaman 
Larutan Lengkuas Terhadap Jumlah Bakteri Ikan Bandeng. Jurnal unimus, 7(1).

Tarwiyah, 2001. Minyak Atsiri Jahe.
Usmiati, S. 2010. Pengawetan Daging Segar dan Olahan. Balai Besar Penelitian dan Pengembangan Pascapanen Pertanian. Bogor. 